STUDIA PRAWNO-EKONOMICZNE, t. CIV, 2017

PL ISSN 0081-6841; e-ISSN 2450-8179 $\quad$ s. 345-358

DOI: 10.26485/SPE/2017/104/20

Radosław ZYZIK*

\title{
OD OPCJI DOMYŚLNEJ DO MANIPULACJI, CZYLI O WYBORZE POMIĘDZY OFE A ZUS. PERSPEKTYWA EKONOMII BEHAWIORALNEJ1
}

\begin{abstract}
(Streszczenie)
Celem artykułu jest odpowiedź na pytanie, czy wykonywanie władzy publicznej polegającej na umożliwianiu wyboru obywatelom spośród prezentowanych przez władzę opcji musi być zawsze uznane za formę manipulacji. W pracy analizowana jest sytuacja decyzyjna związana z wyborem pomiędzy Otwartymi Funduszami Emerytalnymi a Zakładem Ubezpieczeń Społecznych, przed którym stanęli ubezpieczeni w 2014 r. Choć kwestia ta była szeroko dyskutowana przez prawników, ekonomistów i polityków, to aspekt kontekstu decyzyjnego nigdy nie był szczegółowo analizowany. Hipotezy i teorie wypracowane przez ekonomistów behawioralnych pozwalają na naukowe studia nie tylko nad prezentowanymi opcjami planów emerytalnych, ale także nad sposobami prezentacji scenariuszy decyzyjnych i procedurą podjęcia decyzji oraz ich wpływem na treść podejmowanych decyzji. Ekonomiczna analiza sytuacji decyzyjnej pozwala doprecyzować pojęcie manipulacji, jak również wskazać możliwe sposoby jej neutralizowania, a tym samym wykorzystanie ekonomii behawioralnej może mieć również wpływ na demokratyzację procesów decyzyjnych.
\end{abstract}

Słowa kluczowe: manipulacja; opcja domyślna; ZUS; OFE; ekonomia behawioralna

Klasyfikacja JEL: D72

\section{Wstęp}

Twierdzenie, że nikt nie chce być manipulowany ociera się o truizm. Manipulacja na uniwersum relacji społecznych znajduje się niebezpiecznie blisko oszustwa, a oszustwo jest paradygmatycznym przykładem zachowania niemoralnego. To

* Dr, Akademia Ignatianum w Krakowie, Wydział Pedagogiczny, Instytut Nauk o Polityce i Administracji, Katedra Systemów Politycznych; e-mail: radek.zyzik@gmail.com

1 Artykuł został sfinansowany ze środków Narodowego Centrum Nauki przyznanych na realizację projektu o numerze rejestracyjnym 2015/17/D/HS5/00453. 
zaś co niemoralne, bez znaczenia, czy jest zabronione ustawą, zasługuje na społeczne potępienie. Na dodatek w złożonych relacjach społecznych pewna doza zaufania społecznego jest koniecznością, by społeczeństwa mogły właściwie funkcjonować. Tym samym osoba wykorzystująca ten kapitał społeczny, którym jest wzajemne zaufanie między obywatelami, zasługuje na napiętnowanie i odpowiednią karę.

A co w sytuacji, gdy ktoś, komu szczególnie ufamy, naraża się na zarzut manipulacji? Co w sytuacji, gdy tą drugą stroną relacji społecznych jest aktualnie rządząca demokratycznie wybrana władza państwowa? To pytanie jest niezmiennie aktualne od lat, ponieważ każda władza narażona jest na pokusę realizowania własnych zamierzeń, niekiedy wbrew interesom ogółu społeczeństwa, przy wykorzystaniu jak największego spektrum metod i narzędzi. Manipulacja jest niewątpliwie jednym ze sposobów ułatwiających rządzenie, choć zdemaskowanie działań manipulacyjnych może drogo kosztować demokratycznie wybranych polityków.

Jednak jak ocenić sytuację, w której przedstawiciele władzy publicznej wcale nie muszą być świadomi faktu, że stosują techniki manipulacyjne? Postępowanie, które jeszcze dwadzieścia lat temu nie było manipulacją, dziś dzięki postępowi badań prowadzonych przez psychologów poznawczych i ekonomistów behawioralnych rodzi wątpliwości i pytania o etykę postępowania? Czy można oszukiwać mimo woli i manipulować mimo woli?² Oczywiście wszystko zależy od przyjętych definicji, ale to nie semantyka będzie przedmiotem badań, a pewne rzeczywiste procesy decyzyjne $i$ ich konsekwencje mające kluczowe znaczenie dla oceny działań władzy publicznej. Celem prezentowanych w tekście badań jest próba udzielenia odpowiedzi na pytanie, czy w sytuacji, w której władza publiczna prezentuje określone opcje wyboru społeczeństwu, to wybór ten jest zawsze pewną formą manipulacji? Przedmiotem analizy jest sytuacja decyzyjna związana z wyborem pomiędzy Otwartymi Funduszami Emerytalnymi a Zakładem Ubezpieczeń Społecznych, przed którym stanęli ubezpieczeni w 2014 r.

Zanim przejdziemy do poszukiwania odpowiedzi na powyższe pytania należy rzucić trochę światła na samo zjawisko manipulacji. Interesująco przedstawia się źródłosłów łacińskiego pojęcia manipulatio oznaczający manewr, fortel lub podstęp, którego celem jest takie wywarcie wpływu na drugą osobę, grupę osób lub większą jeszcze zbiorowość, by w sposób nieświadomy zrealizowały one

2 Zob. J. Lichtenberg, Paternalism, Manipulation, Freedom, and the Good, w: E. Shafir (red.), The Behavioral Foundations of Public Policy, Princeton University Press, Princeton 2013, s. 494-499. 
cele manipulatora. Co jest jednak w tym tak niestosownego, że na dźwięk słowa manipulacja niemal instynktownie pojawia się negatywna ocena takiego postępowania? Przecież zmotywowanie kogoś do nieświadomego działania wcale nie musi być czymś oczywiście nagannym. Zmobilizowanie kogoś fortelem do dbania o własne zdrowie, do większego wysiłku fizycznego, do uczciwego postępowania, do oszczędzania wcale nie musi automatycznie łączyć się negatywnym oceną̧.

Stownik języka polskiego PWN tak definiuje manipulację: ,wykorzystywanie jakichś okoliczności, naginanie lub przeinaczanie faktów w celu udowodnienia swoich racji lub wpływania na cudze poglądy i zachowania""4.

Wydaje się, że negatywna ocena manipulacji jest związana z obawą, że ktoś może zostać w sposób niezauważony wmanewrowany w działanie wbrew jego własnym interesom, a zmanipulowana osoba nawet nie zauważy, że realizuje interesy kogoś innego. Jego autonomia decyzyjna, zdolność do świadomego i racjonalnego działania zostanie poważnie ograniczona, a gdy fakt ten nie zostanie zauważony, to osoba zmanipulowana, przez pewien przynajmniej czas, będzie bezbronna wobec manipulatora. W demokratycznych społeczeństwach kultury Zachodu wysoko ceni się zdolność do podejmowania samodzielnych decyzji i nie tak łatwo jej członkowie dają ją sobie odbieraćs.

Czy przedstawiciele władzy publicznej powinni powstrzymywać się od sięgania po techniki manipulacyjne? Już na pierwszy rzut oka widać, że mamy do czynienia z kwestią normatywną, a pamiętać należy, co mawiali rzymscy juryści. Rzymska premia głosi, że impossibla nulla obligatio est, czyli niemożliwe nie obowiązuje $^{6}$. Zadajmy raz jeszcze powyższe pytanie tylko z poprawką, którą podsuwają nam rzymscy ojcowie prawa. Czy możliwa jest działalność przedstawicieli władzy, która nie jest manipulacją? Czy przedstawiciele władzy są niejako zmuszani do zachowań manipulacyjnych przez sam proces rządzenia? I wreszcie, czy można oszukiwać mimo woli i manipulować mimo woli? Te ogólne i niejasne pytania nie mają na celu sugerowania makiawelicznej natury władzy publicznej, ale mają zwrócić uwagę na psychologiczne mechanizmy związane z postrzeganiem rzeczywistości. Postrzeganej tak przez obywateli, jak i przez członków administracji państwowej.

3 Zob. R. Thaler, C. Sunstein, Impuls: jak podejmować właściwe decyzje dotyczace zdrowia, dobrobytu i szczęścia, Zysk i S-ka, Poznań 2008.

4 http://sjp.pwn.pl/sjp/manipulacja;2481186; stan na 10.08.2016 r.

5 R. Thaler, C. Sunstein, Libertarian Paternalism, The American Economic Review 2003/2, s. $175-179$.

$6 \mathrm{http} / /$ www.oxfordreference.com/view/10.1093/acref/9780195369380.001.0001/acref-97801953 69380-e-880; stan na 1.08.2016 r. 
Nie chodzi również o wszystkie sposoby rządzenia, ale głównie o takie, w przypadku których rząd wchodzi w mniej lub bardziej bezpośredni dialog z rządzonymi, oczekując od nich ustosunkowania się do własnych zamierzeń. Do przykładów takich form sprawowania rządów można zaliczyć referenda, konsultacje społeczne, lub - jak zobaczymy poniżej - decyzję o wyborze sposobu oszczędzania środków pieniężnych na rzecz przyszłej emerytury. Nie bez znaczenia jest istniejące w zaistniałej sytuacji napięcie pomiędzy chęcią realizacji autorskich zamierzeń aktualnej władzy, koniecznością pewnych posunięć związanych z bieżącą sytuacją polityczna, ekonomiczną lub społeczną, a także niezbędnym dla dalszego rządzenia poparciem społecznym, które łatwo można utracić, zwłaszcza gdy działalność demokratycznie wybranej władzy rozmija się z oczekiwaniami społecznymi.

\section{O nic nierobieniu z perspektywy ekonomii behawioralnej}

Jednym $\mathrm{z}$ bardziej istotnych $-\mathrm{z}$ perspektywy podejmowanego $\mathrm{w}$ niniejszej pracy zagadnienia - faktów naukowych, który dziś zaliczyć możemy do ekonomii behawioralnej ${ }^{7}$, jest twierdzenie, że kontekst decyzyjny (sytuacja decyzyjna, architektura wyboru) ma znaczenie dla rezultatów podejmowanej decyzji ${ }^{8}$. Do kontekstu decyzji zalicza się m.in. kolejność podejmowanych kroków, których celem jest decyzja ${ }^{9}$, rodzaj i liczba podmiotów biorących udział w procesie decyzyjnym $^{10}$, miejsce decydowania ${ }^{11}$, sformułowanie alternatywnych rozwiązań problemu, a tym samym sformułowanie alternatywnych decyzji ${ }^{12}$, koszty związane z decydowaniem, a także konsekwencje niepodjęcia żadnych działań ${ }^{13}$. I choć w różnych sytuacjach jesteśmy tymi samymi osobami z zestawem preferencji, pragnień i potrzeb, to w zależności od zróżnicowanych elementów, składających

7 N. Wilkinson, M. Klaes, An Introduction to Behavioral Economics, Palgrave Macmillan, New York 2012.

8 M. Kelman, Y. Rottenstreich, A. Tversky, Context-Dependence in Legal Decision Making, The Journal of Legal Studies 1996/2, s. 287-318.

9 G. Northcraft, M. Neale, Experts, amateurs, and real estate: An anchoring-and-adjustment perspective on property pricing decisions, Organizational Behavior and Human Decision Processes 1984/1, s. 84-97.

10 J. Surowiecki, The Wisdom of Crowds, Knopf Doubleday Publishing Group, New York 2005.

11 J. Berger, M. Meredith, S. Wheeler, Contextual priming: Where people vote affects how they vote, Proceedings of the National Academy of Sciences 2008/26, s. 8846-8849.

12 A. Tversky, D. Kahneman, Rational Choice and the Framing of Decisions, The Journal of Business 1986/4, s. 251-278.

13 W. Samuelson, R. Zeckhauser, Status quo bias in decision making, Journal of Risk and Uncertainty 1988/1, s. 7-59. 
się na sytuację decyzyjną możemy podejmować różne decyzje. A przecież sama sytuacja decyzyjna nie powinna mieć większego znaczenia. Okazuje się, że jest dokładnie odwrotnie.

Dobrą ilustracją tego stanu rzeczy jest wykorzystywanie przez różne podmioty tzw. opcji domyślnych (default options). Jeśli niedoszły decydent postawiony w sytuacji wyboru nie zrobi nic, wtedy konsekwencja jego braku aktywności staje się opcja domyślna. Na przykład Decydent musi wybrać pomiędzy opcjami X, Y, Z. Jeśli nie dokona wyboru, to automatycznie zostanie przypisana mu opcja Y. Opcje domyślne to rezultaty bierności. Same w sobie nie są ani złe, ani dobre. W niektórych sytuacjach może okazać się, że konkretna opcja domyślna jest czymś pozytywnym na przykład wtedy, gdy automatycznie jesteśmy objęci ubezpieczeniem zdrowotnym, a dopiero na nasze wyraźne życzenie możemy wypisać się z danego planu ubezpieczenia zdrowotnego lub wtedy, gdy automatycznie jesteśmy uznani za dawców organów. Dopiero nasz wyraźny sprzeciw (za życia lub np. w postaci oświadczenia noszonego w portfelu w przypadku nagłej śmierci) uniemożliwia pobranie organów ${ }^{14}$.

Dlaczego ludzie rezygnują z przemyślanych decyzji, podejmowanych po uwzględnieniu istotnych informacji i starannym ważeniu argumentów, a wybierają opcje domyślne, o autorach których niewiele wiedzą (mogą to być firmy, osoby prywatne, instytucje publiczne)? Skłonność do wyboru opcji domyślnych ma trzy główne przyczyny, które można określić skrótowo: wysiłek, implikowane poparcie (implied endorsement) i niechęć do straty ${ }^{15}$.

Wysiłek, trud, przeszkody, wszystko to generuje koszty podejmowanych decyzji. Od kosztów związanych z wydłużonym czasem decydowania, po koszty organizacyjne, na kosztach finansowych kończąc. Koszty to ten element decydowania, którego chcemy uniknąć - jeśli nawet nie za wszelką - to za niekiedy dość wysoką cenę. Ceną taką może być zgoda na sytuację, na którą w razie niewystępowania owych kosztów człowiek nie zgodziłby się. Jeśli więc w naszym interesie leży pojawienie się w jakimś urzędzie, bo w innym przypadku nie uda się nam osiagnąć pewnej korzyści, ale na koszty dotarcia do urzędu składają się koszty dojazdu do innego miasta, konieczność wzięcia dnia wolnego w pracy, znalezienie opieki dla dziecka, to może się okazać, że choć uzyskanie pewnej pomocy lub korzyści od państwa jest kuszące, to wygenerowane koszty są tak

14 S. Davidai, T. Gilovich, L.D. Ross, The meaning of default options for potential organ donors, Proceedings of the National Academy of Sciences 2012/38, s. 15201-15205.

15 E. Johnson, D. Goldstein, Decisions by Default, w: E. Shafir (red.), The Behavioral Foundations of Public Policy, Princeton University Press, Princeton 2013, s. 420. 
wysokie, że osoba postawiona w takiej sytuacji zrezygnuje z podjęcia wysiłku i wybierze status quo ${ }^{16}$.

Innym przykładem wysiłku jest wysiłek - mówiąc kolokwialnie - uświadamiania sobie własnych interesów. Człowiek nie jest zdolny, by ex ante wypracować stały zestaw preferencji w stosunku do wszelkich przyszłych sytuacji i problemów. Jeśli znajdzie się więc w nowej i dość złożonej sytuacji decyzyjnej, to koszt związany $\mathrm{z}$ wypracowaniem własnych preferencji $\mathrm{w}$ stosunku do skomplikowanego problemu, przed którym stoi, może się okazać dla niego zbyt wysoki i wybierze przygotowaną dla niego (przez kogoś innego) opcję domyślną. $Z$ jednej strony pozwoli mu to na wyjście z sytuacji, a z drugiej uwolni go od konieczności konstruowania preferencji w obliczu zaistniałej sytuacji i podjęcia trudnej decyzji ${ }^{17}$.

Ciekawym przykładem rozumienia opcji domyślnych przez obywateli jest uznanie ich jako wskazówek pożądanego działania. Wskazówek, dodajmy, udzielanych przez zatroskanych przedstawicieli władzy publicznej. Jeśli więc pojawia się opcja domyślna, której autorami są przedstawiciele władzy publicznej, to obywatel zakłada, że władza - działając przecież na rzecz dobra wszystkich obywateli - podpowiada, co należy w konkretnej sytuacji uczynić, jednocześnie zachowując wolność decyzyjną i ostatnie słowo dla obywatela. Wybór tak rozumianej opcji domyślnej może również zostać wzmocniony poprzez heurystykę (uproszczoną metodę rozumowania) imitacji polegającej na tym, że obywatele zakładają, że władza publiczna podpowiada takie rozwiązania, za którymi opowiada się większość jej wyborców, a więc jest ona w jakimś stopniu formą wyrażenia woli suwerena poprzez odpowiednio skonstruowaną sytuację decyzyjną ${ }^{18}$.

Ostatnim, ale jakże istotnym powodem bierności decyzyjnej skutkującej w efekcie opcją domyślną jest zjawisko niechęci do straty (loss aversion) i poleganie na punktach odniesienia (reference dependence) ${ }^{19}$. W 1981 r. dwóch psychologów Daniel Kahneman i Amos Tversky zapytało uczestników eksperymentów, którą z zaprezentowanych poniżej strategii zapobiegania groźnej chorobie zagrażającej populacji 600 osób należy zastosować. Pierwszy wybór dotyczył dwóch opcji:

1) ta strategia pozwoli na uratowanie 200 osób;

2) ta strategia pozwoli na uratowanie wszystkich 600 osób z prawdopodobieństwem 33\%, a jednocześnie istnieje możliwość $67 \%$, że nikt nie zostanie uratowany.

6 Ibidem.

17 Ibidem, s. 421.

18 Ibidem.

19 Ibidem, s. 422. 
Każda z tych strategii pozwoli na uratowanie 200 osób, ale w pierwszym przypadku mamy pewną wartość, a w drugim wynik zastosowania strategii prewencyjnej ma charakter probabilistyczny, więc osoby mające skłonność do awersji będą preferowały pierwszą strategię. Nie inaczej było w przeprowadzonym eksperymencie, gdzie ok. 70\% osób wybrało pierwszą opcję. Tversky i Kahneman zaprezentowali podobny wybór innym grupom biorącym udział w eksperymencie. Była to również para strategii, tym razem jednak prezentowała się następująco:

3) zastosowanie tej strategii skończy się śmiercią 400 osób;

4) zastosowanie tej strategii daje 33\% szans na to, że nikt nie umrze i $67 \%$ szans, że cała populacja 600 osób umrze w wyniku choroby.

Strategia 3) i 1) pod względem rezultatów są identyczne, podobnie jak strategia 2) i 4). Jedyną różnicą pomiędzy parami strategii 1) i 2) a 3) i 4) jest różnica w sposobie sformułowania. Pierwsze dwie charakteryzują się akcentem położonym na ratowanie życia, podczas gdy dwie kolejne charakteryzują się opisem, w którym podkreśla się straty w ludziach będące efektem przyjęcia określonego planu działania. Kahneman i Tversky przewidywali, że podział preferencji w drugim przypadku będzie zbliżony do pierwszego wyboru. Okazało się jednak, że uczestnicy eksperymentu w 78\% wybierają strategię 4), a tylko $22 \%$ uczestników wybiera strategię 3). Właśnie ten wpływ sposobu, w jaki formułuje się wybór, na treść samego wyboru Kahneman i Tversky nazwali „efektem ramowania”. Wiedza o efekcie ramowania może zostać wykorzystana do bardziej skutecznego realizowania polityk publicznych. Eksponowanie straty zamiast zysku lub zysku zamiast straty znacząco zmienia atrakcyjność identycznych decyzji $i^{20}$.

Odpowiednio opracowany sposób prezentacji problemu poddanego pod publiczną dyskusję może wpłynąć na kształtowanie się ocen, niezależnie od samej treści i znaczenia poddanej pod dyskusję kwestii. Jeśli więc opcja domyślna zostanie sformułowana w języku zysku, to bez wątpienia skłoni to osoby podejmujące decyzje do bierności i zaakceptowania przygotowanego wcześniej dla nich alternatywnego rozwiązania. Z drugiej strony, jeśli opcja domyślna będzie eksponowała stratę, to istnieje szansa, że decydenci przełamią swoją skłonność do bierności i dokonają aktywnego wyboru, by uniknąć przyjęcia opcji domyślnej.

Ekonomiści behawioralni prowadzili od dłuższego czasu studia nad opcjami domyślnymi, dzięki czemu zostały one uznane za jedno z kluczowych narzędzi w ramach nauki o polityce publicznej ${ }^{21}$. Mając już wiedzę o opcjach domyśl-

20 A. Tversky, D. Kahneman, The framing of decisions and the psychology of choice, Science 1981/4481, s. 453-458.

21 E.J. Johnson, D.G. Goldstein, op. cit. 
nych, przyjrzymy się, jak funkcjonują one w praktyce na przykładzie decyzji, jaką w 2014 r. musieli podjąć Polacy, gdy rząd dał im do wyboru pozostawienie składki w Otwartych Funduszach Emerytalnych lub przeniesienie części składki na subkonto do ZUS.

\section{Od OFE do ZUS. Uliczka jednokierunkowa?}

W 2014 r. przed obywatelami państwa polskiego został postawiony wybór, który miał mieć, jeśli nie kluczowy, to znaczący wpływ na wysokość ich przyszłych emerytur. W zależności od decyzji miały być one niskie lub bardzo niskie. Choć sytuacja mogła wydawać się kluczowa z punktu widzenia każdego ubezpieczonego, to, jak się za chwilę okaże, gdzie znalazła się część składek po 2014 r., miała znaczenie przede wszystkim dla władzy publicznej.

Składka emerytalna wynosiła 19,52\% podstawy wymiaru. Jej największa część, bo aż 12,22\% jest i była niezależnie od decyzji ubezpieczonych odkładana na konto w Zakładzie Ubezpieczeń Społecznych, druga z kolei najwyższa część składki emerytalnej, bo 4,38\%, też trafiała do ZUS, tyle że na subkonto. Wybór osób ubezpieczonych miał dotyczyć pozostałej części składki emerytalnej, czyli 2,92\%, co przy założeniu, że Polak w sektorze przedsiębiorstw zarabiał 4137 zł (przykładowo taka była wysokość płacy wg GUS w lutym 2016 r.), to składka emerytalna wynosiła miesięcznie 807 zł, a jej część, o której ubezpieczeni mieli podjąć decyzję, wynosiła 120 zł miesięcznie ${ }^{22}$.

Jak widać już na pierwszy rzut oka, z punktu widzenia pojedynczego ubezpieczonego decyzja ta wcale nie musiała być brzemienną w skutki, a ewentualny błąd przy jej podjęciu wcale nie musiał być równoznaczny z utratą szansy na przeżycie spokojnej emerytury. Po co więc był ten wybór? Po co było przemeblowywać II filar? Odpowiedź jest prosta, w ZUS nie ma pieniędzy, są jedynie wirtualne zapisy. W OFE są pieniądze, które faktycznie można przenieść, a które mogą uratować rządzących przed powiększaniem deficytu budżetowego lub przynajmniej umożliwić działanie obecnego systemu emerytalnego bez koniecznych reform, które musiałyby być z konieczności trudne do przyjęcia przez społeczeństwo. Dlatego też rządzącym zależało, by bez przymusu zmobilizować ubezpieczonych do dobrowolnego przekazania im zgromadzonych w Otwartych Funduszach środków, które mogłyby zostać natychmiast wykorzystane do wypłacania aktualnych emerytur, a właściciele przeniesionych z OFE środków otrzymaliby na swoich subkontach w ZUS jedynie zapisy na rzecz przyszłych wypłat.

${ }^{22}$ http://forsal.pl/artykuly/931434,znow-mozesz-wybrac-zus-czy-ofe.html; stan na 5.08.2016 r. 
Dyskusja dotycząca przeniesienia środków z OFE do ZUS dotyczyła głównie ekonomicznej sensowności takiego rozwiązania oraz motywów politycznych. Z jednej strony analizowano to, jak takie działania wpłyną na wysokość emerytur, a z drugiej, co stanie się z samymi Funduszami Emerytalnymi. Ponadto duża część sceny politycznej, ta, która nie była akurat częścią koalicji rządzącej, zwracała uwagę na motywy polityczne, a nie ekonomiczne, które jakoby miały stać za decyzją o zubożeniu II filaru. Pytano o cele ekonomiczne i motywy polityczne. Nikt nie zwrócił uwagi na samą sytuację decyzyjną.

Jak pamiętamy, sytuacja decyzyjna czy też kontekst decyzyjny to wszystkie aspekty sytuacji związanej z podejmowaną decyzją. W omawianym przykładzie wybór między OFE a ZUS nie był symetryczny. To znaczy, że ubezpieczeni nie musieli koniecznie wybierać między OFE a ZUS, bo w innym wypadku ich pieniądze przepadną. Wybór był niesymetryczny, ponieważ jeśli ubezpieczeni chcieli pozostać w OFE, to musieli wypełnić specjalny formularz i dostarczyć go do ZUS. W innym wypadku część składki automatycznie zostawała przeniesiona do ZUS. Ubezpieczeni mieli cztery miesiące na wybór ZUS lub OFE. Dotychczasowi członkowie OFE musieli złożyć oświadczenie o chęci pozostania w OFE i dalszym przekazywaniu składki do Otwartych Funduszy. Co ciekawe, dodano opcję zmiany funduszu $\mathrm{z}$ dotychczasowego na inny. Wspomniane oświadczenie należało złożyć $\mathrm{w}$ oddziale ZUS osobiście, za pośrednictwem poczty lub przez Internet. Ta trzecia opcja, choć pozornie najłatwiejsza, w praktyce okazywała się być bardziej skomplikowana, ponieważ jeśli ktoś chciał złożyć oświadczenie drogą internetową, to mógł to zrobić tylko za pośrednictwem platformy PUE ZUS, zanim jednak można było z platformy skorzystać należało stawić się w oddziale ZUS i uwierzytelnić podpis ${ }^{23}$. Dopiero wtedy można było skorzystać z drogi internetowej. Dla porządku należy dodać, że ZUS przyjmuje interesantów w godzinach, w których osoby płacące składkę emerytalną są zazwyczaj w pracy lub do niej właśnie zmierzają. Jeśli ktoś jednak nie chciał pozostawiać swoich 2,92\% swojej składki emerytalnej, to wystarczyło nie robić nic, a pieniądze znajdą się automatycznie na subkoncie. W rezultacie w OFE pozostało tylko 2,5 mln ubezpieczonych ${ }^{24}$.

Sytuacja decyzyjna związana $\mathrm{z}$ wyborem pomiędzy ZUS a OFE preferowała wyraźnie przeniesienie części składki do ZUS. Niemniej trudno byłoby zwolennikom OFE zarzucić władzy państwowej chęć powstrzymania ich przed

23 http://emerytura.gov.pl/wybor-ofezus/najwazniejsze-informacje-ofe-zus/; stan na 5.01.2017 r.

$24 \mathrm{https} / /$ www.analizy.pl/fundusze/wiadomosci/17006/2,5-mln-osob-zostaje-w-ofe.html; stan na 13.08.2016 r. 
oszczędzaniem w II filarze. Państwo niczego w tym przypadku nie zakazywało, nikt przecież nie spotkałby się z kara, gdyby chciał swoje środki pozostawić w OFE. Państwo nie działało w sposób opresyjny, nie wykazało się także w swych działaniach agresywnym paternalizmem. Nie była to w żadnej mierze nacjonalizacja prywatnych środków w celu zmniejszenia deficytu budżetowego i realizacji aktualnych planów budżetowych.

Opcje domyślne to potężna broń będąca w posiadaniu architektów wyboru. Psychologowie przeprowadzili eksperymenty, które miały na celu ustalenie, czy nawet w przypadku tak istotnych kwestii, jak zapisanie się do planów emerytalnych, opcje domyślne znacząco wpływają na rozkład preferencji przyszłych emerytów ${ }^{25}$. Rezultaty zaskoczyły wszystkich, ponieważ jeśli obecnym pracownikom pozostawi się wolność w zakresie samodzielnego zapisu do planu emerytalnego, to tylko $20 \% \mathrm{z}$ nich to robi (65\% po upływie kolejnych trzech miesięcy). Jeśli jednak opcją domyślną jest przystapienie, to ponad 90\% pracowników zostaje objętych obowiązkowym planem oszczędzania na poczet przyszłych emerytur. Odsetek wypisujących się jest znikomy. Ten przykład ilustruje kluczowe znaczenie odpowiednio dobranej opcji domyślnej. Siła inercji nawet w tak ważnych decyzjach jak plan emerytalny może modyfikować decyzje ludzi, którzy nie są nawet tego świadomi.

\section{Zakończenie}

Na początku artykułu postawiono pytanie, czy możliwa jest taka działalność władzy publicznej, która nie jest manipulacją? Chodziło jedynie - jak odnotowano powyżej - o pewne formy działalności związane z dokonywaniem wyborów przez obywateli. W artykule nie były prowadzone pogłębione studia nad samym pojęciem manipulacji, raczej analiza została zatrzymana na poziomie semantycznym i wynikach, z którymi - jak się wydaje - większość czytelników może się zgodzić. Następnie zaprezentowano opcje domyślne jako nowe narzędzie realizacji polityk publicznych, by wreszcie przywołać sytuację, w której w polskich warunkach opcje domyślne zostały wykorzystane, czyli sytuację wyboru pomiędzy pozostawieniem części składki emerytalnej w OFE i przeniesieniem jej do ZUS.

Czy wykorzystywanie opcji domyślnych musi narażać się na zarzut manipulacji? Przyjrzymy się bliżej sytuacji z 2014 r., tym razem z perspektywy tego, co

25 Zob. B. Madrian, D. Shea, The Power of Suggestion: Inertia in 401(k) Participation and Savings Behavior, The Quarterly Journal of Economics 2001/4, s. 1149-1187. 
powiedzieliśmy o opcjach domyślnych. Jeśli ubezpieczeni nie podjęli żadnych działań, to ich składka emerytalna wędrowała do ZUS. Jeśli zaś chcieli, by ich pieniądze pozostały w OFE, musieli włożyć mniej lub więcej wysiłku, by nabyć i złożyć lub wysłać oświadczenie o pozostawaniu w OFE. Nikt, kto ma częsty kontakt z administracją państwową w Polsce, nie dąży do szybkich odwiedzin w urzędach. Niemniej, jeśliby odwrócić asymetrię wyboru, to opcją domyślną byłoby pozostawienie środków w OFE. Czy w takim wypadku nie byłoby zagrożenia, że dopuszczono się manipulacji? Oczywiście byłoby, ale w tym przypadku rezultatem byłaby odmienna decyzja.

W przypadku wyboru pomiędzy ZUS a OFE wydaje się, że głównym motywem takiego, a nie innego skonstruowania sytuacji decyzyjnej była chęć podwyższenia kosztów związanych z pozostaniem w OFE do tego stopnia, by nawet osoby, które w innych warunkach zostałby w OFE, pozwoliły na powrót ich pieniędzy do ZUS. Ta znacząca różnica w kosztach pomiędzy wyborem OFE a ZUS wyraźnie preferowała ZUS i wydaje się, że można z dużą dozą pewności założyć, że taki właśnie cel przyświecał ówczesnej władzy. Dodatkowo ubezpieczeni mogli zakładać, że skoro władza państwowa dopuszcza możliwość, że w razie braku aktywności z ich strony pieniądze trafią do ZUS, to najpewniej jest to najbezpieczniejsza opcja z punktu widzenia wysokości ich przyszłych emerytur. W końcu OFE może zbankrutować, a państwo nie. Na dodatek informacje podawane w trakcie owych czterech miesięcy o znikomej liczbie ludzi pozostawiających swoje środki w OFE sprawiły, że ludzie zaczęli posługiwać się heurystyką imitacji jako metodą pomagającą podjąć decyzję o przeniesieniu środków. Choć ubezpieczeni mieli wolną rękę, to sytuacja decyzyjna przemawiała na niekorzyść OFE.

Richard Thaler i Cass Sunstein, autorzy bestsellerowej książki Impuls ${ }^{26}$, w której prezentują w przystępny sposób wykorzystanie ekonomii behawioralnej w celu wpływania na wybory jednostek, uważają, że nie ma czegoś takiego jak neutralne środowisko wyboru. Treść podejmowanych decyzji w dużej mierze zależy od środowiska decyzyjnego, więc to, w jaki sposób owe środowisko zostało „przygotowane”, ma duże znaczenie. Nawet wiedza o naszej skłonności do wyboru łatwych rozwiązań wcale nie musi stanowić remedium na „pułapkę” opcji domyślnej.

Można jednak zrezygnować z opcji domyślnej na rzecz samodzielnego wyboru, czyli zmusić stosowną regulacją prawną obywateli do zajęcia odpowiedniego stanowiska. Niemniej nie wydaje się, żeby ten sposób postępowania był również

26 R. Thaler, C. Sunstein, Impuls... 
neutralny, ponieważ, jak widzieliśmy na przykładzie niechęci do straty, wystarczy odpowiednio sformułować dostępne opcje, by decydenci byliby bardziej skłonni do wyboru jednej z nich. Poza tym nie wszystkie kwestie mogą być rozstrzygane na zasadzie albo-albo, gdzie dostępne są tylko dwie opcje, a wybór polega na wskazaniu jednej z nich. Niektóre skomplikowane kwestie wymagają większego namysłu i obywatele sami mogą oczekiwać, że władza publiczna niejako zaproponuje im możliwe rozwiązanie nawet wtedy, gdy sami nie zdecydują się na podjęcie decyzji.

Oczywiście istnieje jeszcze możliwość takiego przygotowania sytuacji decyzyjnej, że rezygnacja z opcji domyślnej może być łatwiejsza lub trudniejsza. W takim wypadku ocena, czy mamy do czynienia z manipulacją, czy nie zależałaby od tego, czy z łatwością można uniknąć opcji domyślnej. Pojawiłaby się więc tutaj kwestia ważenia kosztów związanych z rezygnacją. Jeśli owe koszty byłyby niskie, to nawet w nieneutralnej sytuacji decyzyjnej można byłoby mówić o braku technik manipulacyjnych, ponieważ decydenci z łatwością mogą dokonać samodzielnego wyboru. $Z$ drugiej strony, jeśli koszty związane z decyzją są wysokie i np. różnorodne, bo związane z poświęconym czasem, ewentualną podróżą lub środkami finansowymi, to wtedy można domniemywać, że ta asymetria kosztów pomiędzy opcją domyślną a samodzielnym wyborem może wskazywać na chęć manipulacji.

W najszerszym rozumieniu manipulacja to wykorzystywanie dowolnych okoliczności w celu wpływania na zachowania i preferencje innych osób. Biorąc pod uwagę fakt, że być może nie ma neutralnych decyzyjnie kontekstów, w których dokonujemy wyboru, wszystkie powyżej opisane przypadki mogą zostać uznane za manipulację. I choć trudno jest, nawet z semantycznego punktu widzenia, mówić o nieświadomym manipulowaniu, to z perspektywy osób wmanewrowanych w kontekst decyzyjny określonego wyboru nie ma większego znaczenia, czy przedstawiciele władzy publicznej świadomie konstruują w przyjazny dla siebie sposób kontekst, czy robią to intuicyjnie. Definicja manipulacji może być więc doprecyzowana w sposób następujący: jest to takie wykorzystywanie okoliczności w celu wpływania na zachowania innych osób, które wiąże się z wysokimi kosztami wyboru innych, alternatywnych zachowań. Nie będziemy wprost oceniać, czy wybór pomiędzy ZUS a OFE był przykładem świadomego manipulowania zachowaniami ubezpieczonych. Bez wątpienia jednak asymetria kosztów, naturalnie przyjmowane założenie o implikowanym poparciu, posługiwanie się heurystyką imitacji mogą budzić uzasadnione wątpliwości co do intencji osób stojących za skonstruowaniem sytuacji decyzyjnej w omawianym przypadku. 


\section{Bibliografia}

\section{Opracowania}

Berger Jonah, Meredith Mark, Wheeler Christian, Contextual priming: Where people vote affects how they vote, Proceedings of the National Academy of Sciences 2008/26, s. 8846-8849 .

Davidai Shai, Gilovich Thomas, Ross Lee, The meaning of default options for potential organ donors, Proceedings of the National Academy of Sciences 2012/38, s. 15201-15205.

Johnson Eric, Goldstein Daniel, Decisions by Default, w: Eldar Shafir (red.), The Behavioral Foundations of Public Policy, Princeton University Press, Princeton 2013, s. 420.

Kelman Mark, Rottenstreich Yuval, Tversky Amos, Context-Dependence in Legal Decision Making, The Journal of Legal Studies 1996/2, s. 287-318.

Lichtenberg Judith, Paternalism, Manipulation, Freedom, and the Good, w: Eldar Shafir (red.), The Behavioral Foundations of Public Policy, Princeton University Press, Princeton 2013, s. 494-499.

Madrian Brigitte, Shea Dennis, The Power of Suggestion: Inertia in 401(k) Participation and Savings Behavior, The Quarterly Journal of Economics 2001/4, s. 1149-1187.

Northcraft Gregogry, Neale Margareth, Experts, amateurs, and real estate: An anchoring-andadjustment perspective on property pricing decisions, Organizational Behavior and Human Decision Processes 1984/1, s. 84-97.

Samuelson William, Zeckhauser Richard, Status quo bias in decision making, Journal of Risk and Uncertainty 1988/1, s. 7-59.

Surowiecki James, The Wisdom of Crowds, Knopf Doubleday Publishing Group, New York 2005.

Thaler Richard, Sunstein Cass, Impuls: jak podejmować właściwe decyzje dotyczace zdrowia, dobrobytu i szczęścia, Zysk i S-ka, Poznań 2008.

Thaler Richard, Sunstein Cass, Libertarian Paternalism, The American Economic Review 2003/2, s. 175-179.

Tversky Amos, Kahneman Daniel, Rational Choice and the Framing of Decisions, The Journal of Business 1986/4, s. 251-278.

Tversky Amos, Kahneman Daniel, The framing of decisions and the psychology of choice, Science 1981/4481, s. 453-458.

Wilkinson Nick, Klaes Matthias, An Introduction to Behavioral Economics, Palgrave Macmillan, New York 2012.

\section{Strony internetowe}

http://forsal.pl/artykuly/931434,znow-mozesz-wybrac-zus-czy-ofe.html; stan na 5.08.2016 r. http://sjp.pwn.pl/sjp/manipulacja;2481186; stan na 10.08.2016 r.

http://www.oxfordreference.com/view/10.1093/acref/9780195369380.001.0001/acref-97801953 69380-e-880; stan na 1.08.2016 r.

https://www.analizy.pl/fundusze/wiadomosci/17006/2,5-mln-osob-zostaje-w-ofe.html; stan na 13.08.2016 r.

http://emerytura.gov.pl/wybor-ofezus/najwazniejsze-informacje-ofe-zus/; stan na 5.01.2017 r. 
Radosław ZYZIK

\title{
FROM THE DEFAULT OPTIONS TO MANIPULATION - CHOOSING BETWEEN OFE AND ZUS. THE PERSPECTIVE OF BEHAVIORAL ECONOMICS
}

\author{
( Summary)
}

The goal of the paper is to answer the question whether the exercise of public authority, consisting in enabling citizens to choose from the options presented by the authority, must always be regarded as a form of manipulation? The analysis focuses on the decision-making context related to the choice between Open Pension Funds and Social Insurance Institution. Although the issue has been widely discussed by lawyers, economists and politicians, this aspect of the context of decision-making has never been analyzed in detail. Hypotheses and theories developed by behavioral economists allow scientific studies not only on the presented options, retirement plans, but also on ways of presenting scenarios and decision-making procedure to take decisions and their impact on content decisions. Economic analysis of the decision situation can clarify the concept of manipulation, as well as identify possible ways of neutralizing and thus the use of behavioral economics may also affect the democratization of decision-making processes.

Keywords: manipulation; default options; ZUS; OFE; behavioral economics 